\title{
Production of Exo- $\beta-N$-acetylglucosaminidase by Bacillus subtilis B
}

\author{
By J. M. ORTIZ, * R. C. W. BERKELEY AND S. J. BREWER \\ Department of Bacteriology, The Medical School, \\ University Walk, Bristol, BS8 ITD
}

(Received 22 June 1972; revised 28 March 1973)

\section{SUMMAR Y}

Bacillus subtilis B produces $\beta$ - $N$-acetylglucosaminidase both in simple and complex medium during late logarithmic growth. The enzyme is partly associated with the bacteria but does not accumulate within the organism before release. Addition of $\beta-N$-acetylglucosaminides causes an increased differential rate of enzyme synthesis and endogenous inducer may be formed by autolysis. Synthesis of $\beta$-N-acetylglucosaminidase seems to be regulated by a balance of inductive and repressive effects.

\section{INTRODUCTION}

Exo- $\beta-N$-acetylglucosaminidases are widely distributed among bacteria (Berkeley, Drozd \& Broughall, 1969). Other hexosaminidases active against mucopeptide are produced by many bacteria (Higgins \& Shockman, 197I) and these may play a part in bacterial cell wall growth (Braun \& Schwarz, I969). Exo-glucosaminidases are unlikely to open up the mucopeptide sacculus or separate the growing organisms (cf. Rogers, I970) but may bring about fine changes in the aminopolysaccharide chains.

Little is known of the control of hexosaminidase synthesis in bacteria. The formation of a lyzozyme-like lytic enzyme by Bacillus subtilis $\mathrm{R}$ and the existence of endohexosaminidase activity in B. subtilis $\mathrm{I} 68$ have been reported by Richmond (1959) and by Brown \& Young (1970), but little in detail is known about the regulation of these enzymes. Induction and catabolite repression of other extracellular enzymes certainly occurs (May \& Elliot, I968; Tanaka, Fujita \& Hagihira, I969) and a novel system of regulation involving a limitation in the supply of the nucleic acid precursors required for mRNA synthesis has been proposed by Coleman (1967).

This paper describes some factors influencing the formation of Bacillus subtilis в exo- $\beta$ $N$-acetylglucosaminidase and suggests a connexion between this process and autolysis. The isolation and purification (Ortiz, Gillespie \& Berkeley, 1972) and characterization of this enzyme (Berkeley, Brewer, Ortiz \& Gillespie, 1973) have already been described.

\section{METHODS}

Organism. Bacillus subtilis в was obtained from the laboratory collection. Bacillus subtilis I68, I06 Na I and I $4 \mathrm{Na} 2$ were kindly provided by Dr P. Schaeffer.

Culture conditions. Liquid cultures were grown in one of two basal media - PS medium containing (g/rooo ml distilled water): $\mathrm{K}_{2} \mathrm{HPO}_{4}, 0.4 ; \mathrm{MgSO}_{4} \cdot 7 \mathrm{H}_{2} \mathrm{O}, 0.05 ; \mathrm{NaCl}, 0 . \mathrm{I}$;

\footnotetext{
* Present address: Department of Microbiology, University of Washington, Seattle, Washington, 98105 , U.S.A.
} 
$\mathrm{FeCl}_{2} .6 \mathrm{H}_{2} \mathrm{O}, 0 . \mathrm{I} 7 ;\left(\mathrm{NH}_{4}\right)_{2} \mathrm{HPO}_{4}$, 0.5; Bacto Peptone, 5.0; and MS Medium containing (g/I000 ml distilled water): $\mathrm{K}_{2} \mathrm{HPO}_{4}, \mathrm{I} 4.0 ; \mathrm{KH}_{2} \mathrm{PO}_{4}, 6.0 ; \mathrm{MgSO}_{4} \cdot 7 \mathrm{H}_{2} \mathrm{O}, 0.5 ;\left(\mathrm{NH}_{4}\right)_{2} \mathrm{SO}_{4}$, 2.0. To these, sterile solutions of carbon sources were added to give the required final concentration. When glucose (0.1 \%) was used the media are referred to as GPS and GMS respectively.

Cultures were grown in Erlenmeyer flasks containing $20 \%$ or less of the flask volume of medium. The flasks were shaken at $37^{\circ} \mathrm{C}$ in an orbital incubator (225 rev./min; $32 \mathrm{~mm}$ throw) and growth followed by extinction $(E)$ readings at $675 \mathrm{~nm}$.

Enzyme assays. $\beta$ - $N$-Acetylglucosaminidase was estimated by the method of Woollen, Heyworth \& Walker (I96I) using $p$-nitrophenyl-2-acetamido-2-deoxyglucose ( $p$ NPGNAc). Alternatively, the fluorimetric method of Leaback \& Walker (I96I) was used with 4-methylumbelliferyl-2-acetamido-2-deoxyglucose as substrate.

Inducers. Micrococcus lysodeikticus walls were prepared by the method of Wadström \& Hisatsune (1970). Bacillus subtilis B walls were prepared by a similar method except that the starting material was bacteria from late exponential phase GPS cultures and that the organisms were disintegrated by sonication. The wall material was resuspended to a concentration of $5 \mathrm{mg} / \mathrm{ml}$ in $30 \mathrm{ml}$ of $0.5 \mathrm{M}$-sodium phosphate buffer, $\mathrm{pH} 6.5$. Lysozyme (Sigma Grade I) was then added to give a final concentration of $0.1 \mathrm{mg} / \mathrm{ml}$ and the digest incubated with shaking at $37^{\circ} \mathrm{C}$ until no further decrease in extinction occurred. Lower mol. wt. material was extracted by dialysis for $20 \mathrm{~h}$ against $200 \mathrm{ml}$ of distilled water and nondiffusable material sterilized by autoclaving at $\mathrm{ro} \mathrm{lb}$ for $20 \mathrm{~min}$.

Chitin oligosaccharides. These were prepared as described by Berkeley, Brewer \& Ortiz (1972).

$N$-acetylamino sugar determination. The method of Reissig, Strominger \& Leloir (1955) was used.

\section{RESULTS}

Bacillus subtilis в produced at least three times more enzyme in GPS at the stationary phase than B. subtilis I68, Marburg, I06 Na I, I4 Na 2 and CS and at least twenty times more than one $B$. cereus and one $B$. megaterium strain.

\section{Growth of Bacillus subtilis в and production of $\beta$ - $N$-acetylglucosaminidase}

Bacillus subtilis B grew with a doubling time of about $60 \mathrm{~min}$ in GMS medium. No $\beta$ - $N$-acetylglucosaminidase was detected during the early stages of exponential growth even using the sensitive fluorimetric assay method to detect enzyme, but as growth slowed enzyme appeared and its rate of formation increased rapidly, both in absolute and differential terms, for about $3 \mathrm{~h}$ (Fig. I).

Bacillus subtilis в initially grew faster in GPS (doubling time $=30 \mathrm{~min}$ ) than in GMS medium and higher differential rates of enzyme synthesis were reached. Omission of glucose from GPS (PS medium) led to a reduced differential rate of enzyme formation but replacement by either succinate (IO $\mathrm{mM}$ ) or glycerol (IO mM) gave a rate above that found in GPS. A characteristic two-phase growth curve was obtained in all these media and enzyme formation was always confined to the second period of growth which coincided with the exhaustion of glucose in the GPS medium.

Dry-weight determinations showed that during the transition from rapid to slower growth some bacterial lysis occurred. 


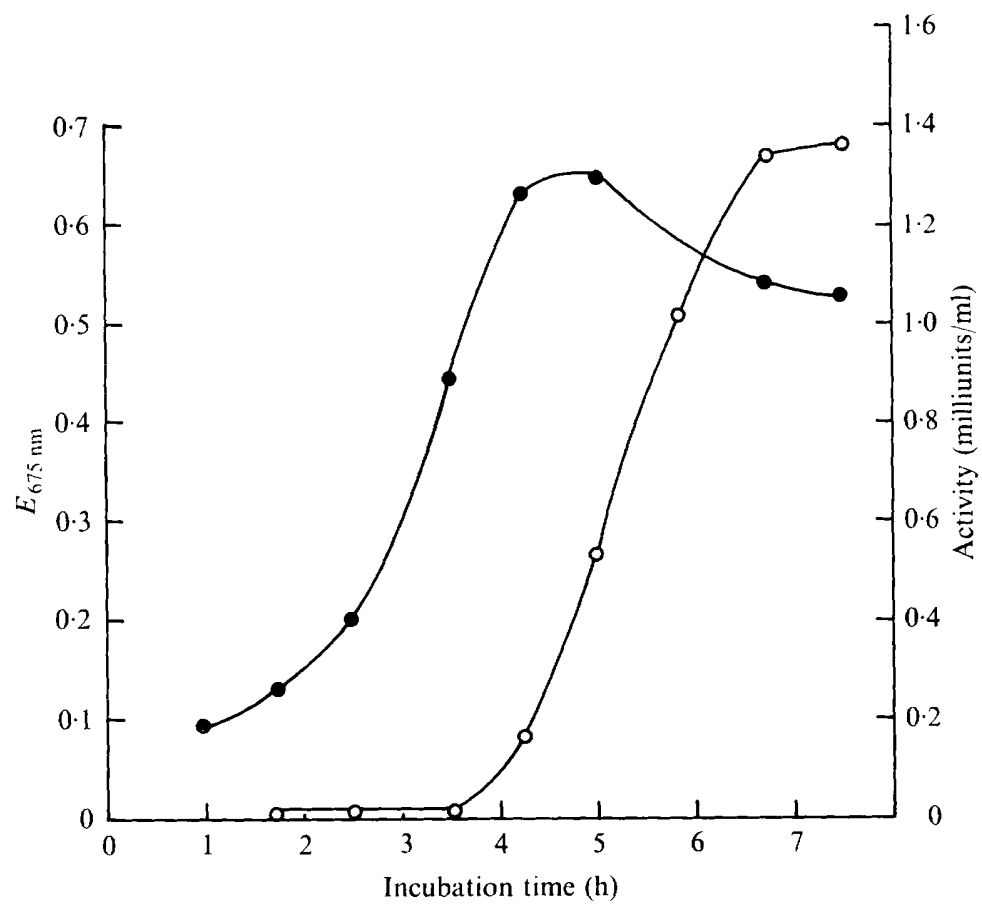

Fig. I. Growth of Bacillus subtilis B and formation of exo- $\beta$ - $N$-acetylglucosaminidase in GMS medium. Growth (O-O); enzyme activity $(\mathrm{O}-\mathrm{O})$.

\section{Table I. Distribution of exo- $\beta$ - $N$-acetylglucosaminidase in Bacillus subtilis B} cultures growing in GPS medium

Enzyme activities in the total culture were assayed, as described in the methods section, on samples withdrawn at the points indicated. The cell bound and extracellular activities were determined as follows: Samples $(5 \mathrm{ml})$ were withdrawn from the cultures and centrifuged at $2000 \mathrm{~g}$ for $15 \mathrm{~min}$ at room temperature. The supernatant was decanted and used for assay of extracellular activity. The bacterial pellets were resuspended to the initial volume in $0.1 \mathrm{M}$-sodium phosphate buffer, $\mathrm{pH} 5.9$, and activities assayed. Sample points $\mathrm{I}-4$ in the Table correspond to samples taken I, 2, 3 and $4 \mathrm{~h}$ respectively after the appearance of enzyme.

Enzyme activity

\begin{tabular}{|c|c|c|c|c|c|c|c|c|}
\hline \multirow{4}{*}{$\begin{array}{l}\text { Sample point ... } \\
\text { Culture density } \\
\quad\left(E_{675 n m}\right) \ldots\end{array}$} & \multirow{2}{*}{\multicolumn{2}{|c|}{ I }} & & & \\
\hline & & & \multicolumn{2}{|c|}{2} & \multicolumn{2}{|c|}{3} & 4 & \\
\hline & \multicolumn{2}{|c|}{$I \cdot I 8$} & \multicolumn{2}{|c|}{$I \cdot 29$} & \multicolumn{2}{|c|}{$\mathrm{I} \cdot 59$} & \multicolumn{2}{|c|}{$2 \cdot 04$} \\
\hline & $\begin{array}{l}\text { Enzyme } \\
(\mathrm{mU} / \mathrm{ml})\end{array}$ & $\begin{array}{c}\% \\
\text { total }\end{array}$ & $\begin{array}{l}\text { Enzyme } \\
(\mathrm{mU} / \mathrm{ml})\end{array}$ & $\begin{array}{c}\% \\
\text { total }\end{array}$ & $\begin{array}{l}\text { Enzyme } \\
(\mathrm{mU} / \mathrm{ml})\end{array}$ & $\begin{array}{c}\% \\
\text { total }\end{array}$ & $\begin{array}{c}\text { Enzyme } \\
(\mathrm{mU} / \mathrm{ml})\end{array}$ & $\begin{array}{c}\% \\
\text { total }\end{array}$ \\
\hline Total culture & 0.67 & 100 & $2 \cdot 50$ & 100 & 4.50 & 100 & 5.67 & 100 \\
\hline Extracellular & 0.50 & 75 & $1 \cdot 50$ & 60 & $3 \cdot 83$ & 85 & $5 \cdot 33$ & 94 \\
\hline Cell bound & 0 & 0 & 0.50 & 20 & 0.50 & I I & 0.33 & 6 \\
\hline
\end{tabular}

Distribution of $\beta$-N-acetylglucosaminidase in cultures of Bacillus subtilis $\mathbf{B}$

Table I summarizes the distribution of $\beta-N$-acetylglucosaminidase in cultures growing in GPS medium. Although the total amount of enzyme increased rapidly over the experimental period the proportion bound to the bacteria was small and more or less constant. Disruption of the culture by ultrasound increased neither the total amount of the enzyme in the culture 


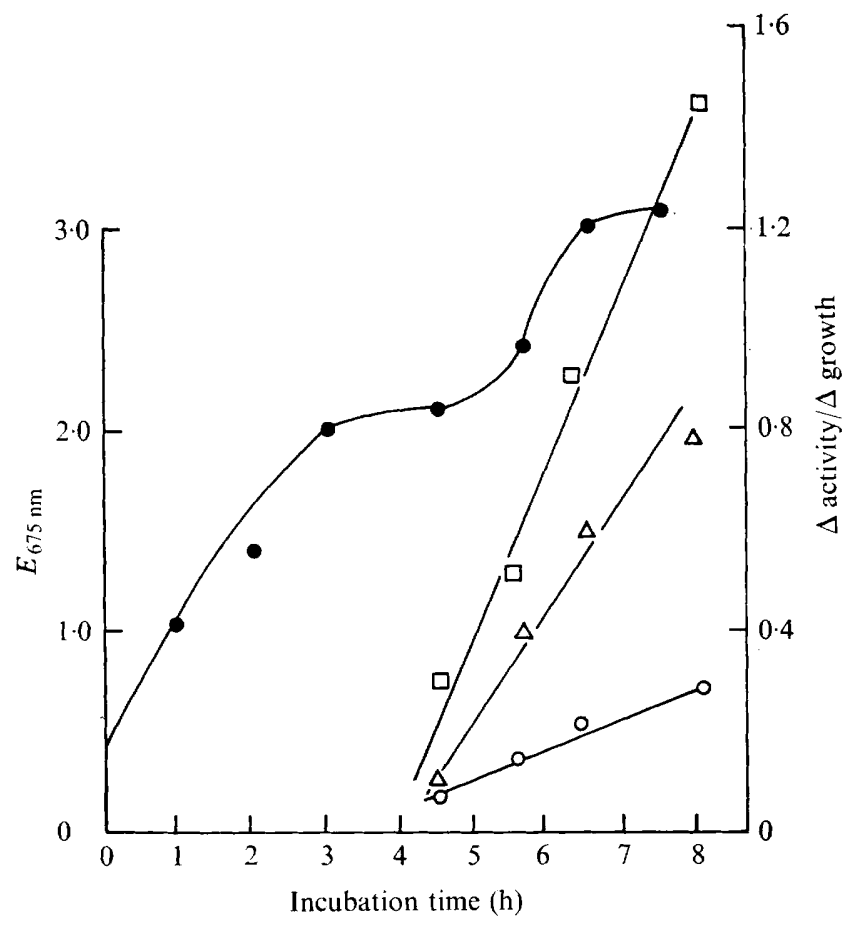

Fig. 2. The effect of $\beta-N$-acetylglucosaminides on the differential rate of exo- $\beta-N$-acetylglucosaminidase formation by Bacillus subtilis B grown in GPS medium. A culture was grown to an $E$ of $\mathrm{I} \cdot 0$ and divided into three portions. To one no addition was made, to another was added chitin hydrolysate to a final concentration of $0.4 \mathrm{mg} / \mathrm{ml}$ and to the other $B$. subtilis B wall material also to a final concentration of $0.4 \mathrm{mg} / \mathrm{ml}$. Growth (-O); differential rate of enzyme formation in control $(O-O)$, in the presence of chitin hydrolysate $(\triangle-\triangle)$ and in the presence of $B$. subtilis $\mathbf{B}$ wall material $(\square-\square)$.

nor the amount associated with the bacterial debris. Addition of chloramphenicol to the culture in the course of an experiment of the type shown in Table I immediately stopped enzyme formation. The enzyme seems to be a true extracellular enzyme as defined by Pollock (1962) and its formation is closely coupled to protein synthesis.

\section{The effect of $\beta-N$-acetylglucosaminides on $\beta$ - $N$-acetylglucosaminidase formation}

Addition of chitin hydrolysates $(0.4 \mathrm{mg} / \mathrm{ml}$ culture) or a wall preparation from Bacillus subtilis в (also $0.4 \mathrm{mg} / \mathrm{ml}$ ) enhanced $\beta$ - $N$-acetylglucosaminidase formation during growth in GPS medium (Fig. 2), but neither preparation caused enzyme activity to appear before growth slowed. The only effect was to increase the differential rate of formation in the second period of growth regardless of the time at which they were added to the culture. Chitin hydrolysate enhanced the rate threefold and wall preparation sixfold, but the total amount of enzyme in the control ultimately reached the same level as that in the induced cultures. Lysozyme digests of walls were more active than intact walls and the non-dialysable part of the digests was about 10 times more effective on a dry weight basis than undigested material and this has been routinely used as enzyme inducer in subsequent experiments.

Various chitin oligosaccharides and two synthetic hexosaminides were also tested as inducers under similar conditions. Only the oligosaccharides were effective inducers but to a lesser extent than the cell wall fragments. Once again the effect only occurred after the 


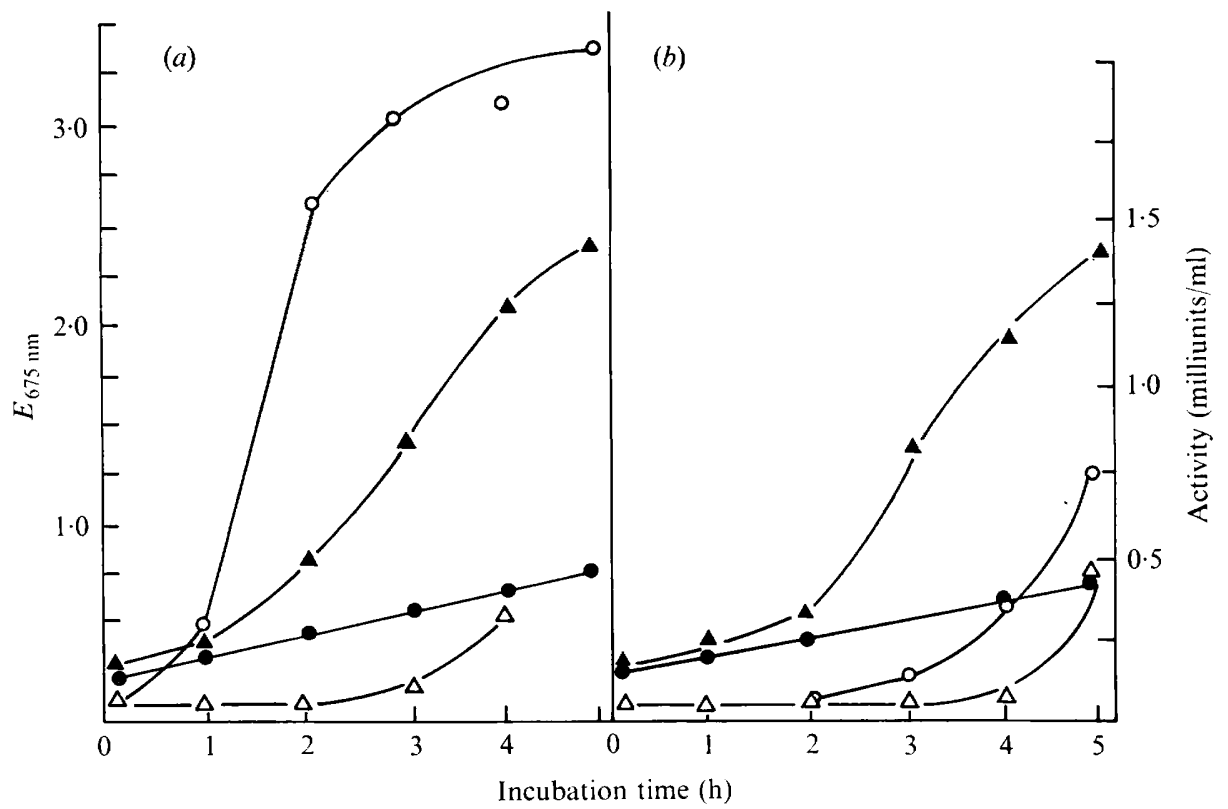

Fig. 3. The effect of glucose and succinate on the induction of exo- $\beta$ - $N$-acetylglucosaminidase. A culture was grown to an $E$ of 0.37 in GPS, the cells collected by centrifugation and resuspended to an $E$ of 0.05 in prewarmed GMS and SMS (a) with and $(b)$ without inducer. Growth (GMS $\Delta-\Delta$; SMS $\bullet$ ) and enzyme production (GMS $\triangle-\triangle$; SMS $\bigcirc-O$ ) were followed.

transition from rapid to slower growth and it seems that autolysis may provide these in cultures to which no exogenous inducer has been added.

The effect of different $C$ sources on $\beta$ - $N$-acetylglucosaminidase formation in the presence of inducer

The effect of modifying the composition of the growth medium on enzyme formation was studied in the presence of the non-dialysable fraction of wall digests (Fig. 3). As expected from previous experiments (see Fig. 2) the presence of inducer enhanced enzyme formation in both instances, but when glucose was present the increase was only slight as compared to that in the succinate medium.

L-Glutamate, citrate, acetate, glycerol and maltose were compared with glucose and succinate for their effect on $\beta$-N-acetylglucosaminidase formation. The first three behaved like succinate and permitted linear induction of enzyme formation. Maltose behaved like glycerol and in these two instances the initial rate of induction was not sustained. Glucose and peptone completely supressed enzyme formation during the experimental period. The behaviour of all these molecules was, therefore, consistent with their position in bacterial intermediary metabolism and probably explains our inability to induce early exponential cultures in media containing peptone.

In the absence of repressive compounds, $\beta$ - $N$-acetylglucosaminidase can be induced throughout the growth cycle by the addition of lysozyme $(0.5 \mathrm{mg} / \mathrm{ml})$. This addition causes a fall in extinction but after growth was resumed, induced levels of enzyme were formed. 


\section{DISCUSSION}

Two methods for the regulation of extracellular enzyme synthesis have been proposed so far. In the first, enzyme synthesis is influenced by the concentration of precursors for mRNA synthesis (Coleman, 1967), while in the second the level of enzyme expression is set by the balance between substrate induction and catabolite repression (Tanaka, Fujita \& Hagihira, 1969). The differential rate of $\beta$ - $N$-acetylglucosaminidase synthesis in Bacillus subtilis B may be increased either by the addition of exogenous $\beta-N$-acetylglucosaminides or by the omission of glucose from the medium, so the synthesis of this enzyme seems to be regulated in this strain by the second of the two methods outlined above. In this respect, therefore, $\beta$ - $N$-acetylglucosaminidase is similar to a number of other microbial glycosidases (Hulme \& Stranks, I971; Lilly \& Bull, 1972).

The inducing effect of wall digests suggests that the inducer of this enzyme in Bacillus subtilis в has a relatively high mol. wt., and analogous conclusions were reached by Rogers (I945, I946) who showed that streptococcal hyaluronidase was induced by hyaluronate, or by the non-diffusable fraction formed from hyaluronate by hyaluronidase action, but not by the products of mild acid hydrolysis. The ability of lysozyme to cause induction of $\beta$ - $N$-acetylglucosaminidase in $B$. subtilis в suggests that the synthesis of the enzyme may depend on production of inducer by autolysin, but the kinetics of production of the enzyme indicate that it is unlikely that the enzyme has an essential role in all growth and division.

We wish to acknowledge a fellowship from the Spanish Ministry of Education and Science (J. M. O.) and support from the Science Research Council. We thank Professor M. H. Richmond for helpful discussion and assistance in the preparation of this paper.

\section{REFERENCES}

Berkeley, R. C. W., Brewer, S. J. \& Ortiz, J. M. (1972). Preparation of 2-acetamido-2-deoxy- $\beta$-Dglucose oligosaccharides from acid hydrolysates of chitin by electrolytic desalting and exclusion chromatography. Analytical Biochemistry 46, 687-690.

Berkeley, R. C. W., Brewer, S. J., OrtiZ, J. M. \& Gillespie, J. B. (I973). An exo- $\beta$ - $N$-acetylglucosaminidase from Bacillus subtilis B: characterization. Biochimica et biophysica acta 309, 157-168.

Berkeley, R. C. W., Drozd, J. W. \& Broughall, J. M. (I969). Bacterial $N$-acetyl- $\beta$-glucosaminidases. Proceedings of the Society of General Microbiology 57, xvi-xvii.

Braun, V. \& Schwarz, U. (1969). Structure, function and biosynthesis of the rigid layer of the Escherichia coli cell wall. Proceedings of the Society for General Microbiology 57, iii.

Brown, W. C. \& Young, F. E. (1970). Dynamic interactions between cell wall polymers, extracellular proteases and autolytic enzymes. Biochemical and Biophysical Research Communications 38, 564-568.

ColEman, G. (1967). Studies on the regulation of extracellular enzyme formation by Bacillus subtilis. Journal of General Microbiology 49, 42 I-43I.

Higgins, M. L. \& Shockman, G. D. (I97I). Procaryotic cell division with respect to wall and membranes. Chemical Rubber Company Critical Reviews in Microbiology 1, 29-72.

Hulme, M. A. \& Stranks, D. W. (I97I). Regulation of cellulase production by Myrothecium verrucaria grown on non-cellulosic substrates. Journal of General Microbiology 69, I45-I 55.

Leaback, D. H. \& Walker, P. G. (I96I). Studies on glucosaminidase 4. The fluorimetric assay of $N$ acetyl- $\beta$-glucosaminidase. Biochemical Journal 78, I5I-1 56.

Lilley, G. \& Bull, A. T. (1972). $\beta$-I,3-glucanase production by a thermophilic streptomycete. Proceedings of the Society for General Microbiology $7 \mathbf{1}$, ix.

MAY, B. K. \& Ellıot, W. H. (1968). Characteristics of extracellular protease formation and its control by amino acid repression. Biochimica et biophysica acta $\mathbf{5 7}, 607-6 \mathrm{I} 5$.

Ortiz, J. M., Gillespie, J. B. \& Berkeley, R. C. W. (I972). An exo- $\beta$ - $N$-acetylglucosaminidase from Bacillus subtilis B; extraction and purification. Biochimica et biophysica acta 289, 174-186. 
Pollock, M. R. (1962). Exoenzymes. In The Bacteria, vol. 4, pp. 121-178. Edited by I. C. Gunsalos and R. Y. Stanier. New York and London: Academic Press.

Reissig, J. L., Strominger, J. L. \& Leloir, L. F. (1955). A modified colorimetric method for the estimation of $\mathrm{N}$-acetylamino sugars. Journal of Biological Chemistry 217, 959-966.

Richmond, M. H. (1959). Formation of a lytic enzyme by a strain of Bacillus subtilis. Biochimica et biophysica acta 33, 78-9I.

RoGERs, H. J. (1945). The conditions controlling the production of hyaluronidase by micro-organisms grown in simplified media. Biochemical Journal 39, 435-443.

Rogers, H. J. (I946). The influence of hydrolysates of hyaluronate upon hyaluronidase production by microorganisms. Biochemical Journal 40, 583-588.

Rogers, H. J. (1970). Bacterial growth and the cell envelope. Bacteriological Reviews 34, 194-214.

TANAKA, S., FujITA, T. \& HAGIHIRA, H. (1969). Regulation of amylase formation by Vibrio parahaemolyticus. Biken Journal I2, I I9-124.

Wadström, T. \& HisATSUne, K. (1970). Bacteriolytic enzymes from Staphylococcus aureus. Specificity of action of an endo- $\beta-N$-acetylglucosaminidase. Biochemical Journal 120, 735-744.

Woollen, J. W., Heyworth, R. \& Walker, P. G. (I961). Studies on glucosaminidase 3. Testicular $N$ acetyl- $\beta$-galactosaminidase. Biochemical Journal 78, I I I-I I6. 